\title{
Cytogenetic analysis of five Ctenidae species (Araneae): detection of heterochromatin and I8S rDNA sites
}

\author{
Matheus Pires Rincão', João Lucas Chavari², \\ Antonio Domingos Brescovit ${ }^{2}$, Ana Lúcia Dias' \\ I Laboratory of Animal Cytogenetics; Department of General Biology, CCB, Universidade Estadual de Londrina. \\ Rodovia Celso Garcia Cid, PR 445, km 380, Londrina-Brasil 2 Special Laboratory of Biological Collections, \\ Instituto Butantan, São Paulo, Brazil \\ Corresponding author: Matheus Pires Rincão (rincaom@gmail.com)
}

Academic editor: J. Král | Received 23 September 2016 | Accepted 19 July 2017 | Published 14 September 2017

http://zoobank.org/43C531D9-727A-4EBD-B293-F1B22BB1F854

Citation: Rincão MP, Chavari JL, Brescovit AD, Dias AL (2017) Cytogenetic analysis of five Ctenidae species (Araneae): detection of heterochromatin and 18S rDNA sites. Comparative Cytogenetics 11(4): 627-639. https://doi.org/10.3897/ CompCytogen.v11i4.10620

\begin{abstract}
The present study aimed to cytogenetically analyse five Ctenidae species Ctenus ornatus (Keyserling, 1877), Ctenus medius (Keyserling, 1891), Phoneutria nigriventer (Keyserling, 1891), Viracucha andicola (Simon, 1906), and Enoploctenus cyclothorax (Philip Bertkau, 1880), from Brazil. All species presented a $2 \mathrm{n} \hat{O}=28$ except for $V$. andicola, which showed $2 \mathrm{n} \hat{O}=29$. Analysis of segregation and behavior of sex chromosomes during male meiosis showed a sex chromosome system of the type $\mathrm{X}_{1} \mathrm{X}_{2} 0$ in species with 28 chromosomes and $\mathrm{X}_{1} \mathrm{X}_{2} \mathrm{X}_{3} 0$ in $V$. andicola. $\mathrm{C}$ banding stained with fluorochromes $\mathrm{CMA}_{3}$ and DAPI revealed two distributions patterns of GC-rich heterochromatin: (i) in terminal regions of most chromosomes, as presented in C. medius, P. nigriventer, E. cyclothorax and V. andicola and (ii) in interstitial regions of most chromosomes, in addition to terminal regions, as observed for $C$. ornatus. The population of Ubatuba (São Paulo State) of this same species displayed an additional accumulation of GC-rich heterochromatin in one bivalent. Fluorescent in situ hybridization revealed that this bivalent corresponded to the NOR-bearing chromosome pair. All analyzed species have one bivalent with $18 \mathrm{~S}$ rDNA site, except P. nigriventer, which has three bivalents with $18 \mathrm{~S}$ rDNA site. Karyotypes of two species, C. medius and $E$. cyclothorax, are described for the first time. The latter species is the first karyotyped representative of the subfamily Acantheinae. Finally, $18 \mathrm{~S}$ rDNA probe is used for the first time in Ctenidae at the present study.
\end{abstract}

\section{Keywords}

C-banding, FISH, fluorochrome, meiosis, spider cytogenetics, sex chromosomes

Copyright Matheus Pires Rincão et al.. This is an open access article distributed under the terms of the Creative Commons Attribution License (CC BY 4.0), which permits unrestricted use, distribution, and reproduction in any medium, provided the original author and source are credited. 


\section{Introduction}

Ctenidae is a family of Araneae distributed throughout the tropical region of the planet (World Spider Catalog 2017). This family includes wandering and nocturnal spiders, with some species of medical interest, such as those of the genus Phoneutria Perty, 1833 (Ministério da Saúde 2017). Ctenidae is divided into five subfamilies, namely Acanthocteninae, Viridasiinae, Cteninae, Calocteninae, and Acantheinae (Silva-Dávila 2003; Polotow and Brescovit 2014). Although ctenids are of great ecological and medical importance, studies on their cytogenetics are scarce (Table 1) and cytogenetic data for the last two subfamilies are not available to date.

Three karyotypes have been observed in the family: (i) $2 \mathrm{n} \hat{0}=22\left(20+\mathrm{X}_{1} \mathrm{X}_{2} 0\right)$; (ii) $2 \mathrm{n}{ }^{\hat{n}}=28\left(26+\mathrm{X}_{1} \mathrm{X}_{2} 0\right)$; and (iii) $2 \mathrm{n} \hat{O}^{\hat{\theta}}=29\left(26+\mathrm{X}_{1} \mathrm{X}_{2} \mathrm{X}_{3} 0\right)$ (Table 1). The sex chromosome systems (SCS) in spiders are considered highly diverse by many authors (Král et al. 2006; 2011; Araujo et al. 2012) ranging from simple systems, such as XY or X0, to multiple SCS as $X_{n} Y_{n}$ or $X_{n} 0$ (Araujo et al. 2017). Based on findings in a specimen of Ctenus ornatus (Keyserling, 1877) Araujo et al. (2014) suggested that the $\mathrm{X}_{1} \mathrm{X}_{2} \mathrm{X}_{3} 0$ system in Ctenidae, might have arisen from a supernumerary chromosome and, according to literature evidence, this system arose repeatedly in the evolutionary history of Entelegynae and its conversion into the $\mathrm{X}_{1} \mathrm{X}_{2} 0$ system and vice-versa is a recurring event. Bole-Gowda (1952) also suggested the involvement of a supernumerary element in the origin of the $\mathrm{X}_{3}$ chromosome in Sparassidae species. Other hypotheses on the conversion of a $\mathrm{X}_{1} \mathrm{X}_{2} 0$ into a $\mathrm{X}_{1} \mathrm{X}_{2} \mathrm{X}_{3} 0$ were also proposed by some authors (Pätau 1948; Postiglioni and Brum-Zorrilla 1981; Parida and Sharma 1986). The conversion of a $\mathrm{X}_{1} \mathrm{X}_{2} \mathrm{X}_{3} 0$ into a $\mathrm{X}_{1} \mathrm{X}_{2} 0$ was firstly proposed in the spider genus Malthonica Simon, 1898 (Agelenidae) by Král (2007), suggesting that tandem fusions occurred in this process.

Chromosome banding techniques, as identification of nucleolus organizer regions (NORs) using silver nitrate impregnation, have been performed in Ctenidae. Araujo et al. (2014) found a single terminal NOR on one autosomal pair in $C$. ornatus and Phoneutria nigriventer (Keyserling, 1891), and on two pairs in Viracucha andicola (Simon, 1906). Kumar et al. (2016) also detected NORs on two autosomal pairs in Ctenus indicus (Gravely, 1931). However, molecular cytogenetic studies are scarce in spiders. There have been only five studies about distribution of some sequences using fluorescence in situ hybridization (FISH): location of $18 \mathrm{~S}$ rDNA sites in Wadicosa fidelis (O. Pickard-Cambridge, 1872) (Lycosidae) (Forman et al. 2013) and Brachypelma albopilosum Valerio, 1980 (Theraphosidae) (Král et al. 2013); 5S rDNA sites in Oxyopes sertatus L. Koch, 1878 (Oxyopidae) (Suzuki and Kubota 2011); mapping of silk genes in Latrodectus hesperus Chamberlin \& Ivie, 1935 and Latrodectus geometricus C. L. Koch, 1841 (Theridiidae) (Zhao et al. 2010); and ocurrence of telomeric repeats in Brachypelma albopilosa Valerio, 1980 (Vítková et al. 2005).

Considering the great importance of ctenids and the scarcity of cytogenetic studies in the group, our study analyzed the mitotic and meiotic chromosomes of five species 
Table I. Cytogenetic data of Ctenidae species, updated from Araujo et al. (2014), including the data of present study. NOR = nucleolus organizer region.

\begin{tabular}{|c|c|c|c|c|}
\hline \multirow[b]{2}{*}{ Species } & \multirow[b]{2}{*}{ Karyotype $\left({ }^{\lambda}\right)$} & \multicolumn{2}{|c|}{ NORs } & \multirow[b]{2}{*}{ Reference } \\
\hline & & $\begin{array}{c}\text { Silver } \\
\text { Nitrate }\end{array}$ & \begin{tabular}{|c} 
detection of \\
18S rDNA
\end{tabular} & \\
\hline \multicolumn{5}{|l|}{ Acantheinae } \\
\hline Enoploctenus cyclothorax (Bertkau, 1880) & $28, X_{1} X_{2} 0$ & & 2 & Present study \\
\hline \multicolumn{5}{|l|}{ Acanthocteninae } \\
\hline Nothroctenus sp. & $29, X_{1} X_{2} X_{3} 0$ & & & Araujo et al. 2014 \\
\hline \multirow{2}{*}{ Viracucha andicola (Simon, 1906) } & \multirow{2}{*}{$29, X_{1} X_{2} X_{3} 0$} & 4 & & Araujo et al. 2014 \\
\hline & & & 2 & Present study \\
\hline \multicolumn{5}{|l|}{ Cteninae } \\
\hline Anahita fauna Karsch, 1879 & $29, X_{1} X_{2} X_{3} 0$ & & & Chen, 1999 \\
\hline Ctenus indicus (Gravely, 1931) & $28, \mathrm{X}_{1} \mathrm{X}_{2} 0$ & 4 & & Kumar et al. 2016 \\
\hline Ctenus medius Keyserling, 1891 & $28, X_{1} X_{2} 0$ & & 2 & Present study \\
\hline Ctenus ornatus (Keyserling, 1877) & $28, X_{1} X_{2} 0$ & 2 & & Araujo et al. 2014 \\
\hline Ctenus sp. & $28, X_{1} X_{2} 0$ & & & Araujo et al. 2014 \\
\hline Parabatina brevipes (Keyserling, 1891) & $28, X_{1} X_{2} 0$ & & & Araujo et al. 2014 \\
\hline \multirow{2}{*}{ Phoneutria nigriventer (Keyserling, 1891) } & \multirow{2}{*}{$28, X_{1} X_{2} 0$} & 2 & & Araujo et al. 2014 \\
\hline & & & 6 & Present study \\
\hline \multicolumn{5}{|l|}{ Viridasiinae } \\
\hline Asthenoctenus borelli Simon, 1897 & $22, X_{1} X_{2} 0$ & & & Araujo et al. 2014 \\
\hline
\end{tabular}

of this family. To understand better the karyotype structure in this group of spiders, we evaluated the behavior of sex chromosomes, heterochromatin composition/distribution pattern, and the location of $18 \mathrm{~S}$ rDNA sites.

\section{Material and methods}

\section{Specimen deposition}

Adults and juveniles of five ctenid species from different collection sites in Brazil were analyzed, as listed in Table 2. Specimens were deposited in the arachnological collection of the Laboratório Especial de Coleçôes Biológicas at Instituto Butantan (IBSP, curator A. D. Brescovit), São Paulo/SP (São Paulo state), Brazil.

\section{Chromosome preparations and banding}

Chromosomal preparations were obtained according to Araujo et al. (2008), with some modifications as follows. After the fixation, testes were dissociated in a drop of $60 \%$ acetic acid on the surface of a microscope slide and covered with a coverslip, pressed and immersed in liquid nitrogen to allow the removal of the coverslip. The diploid number was determined by counting 30 meiotic and mitotic cells. The morphology of 
Table 2. List of collected species, with the number of the individuals, collection sites, and voucher numbers. PR = Paraná State. $\mathrm{SP}=$ São Paulo State.

\begin{tabular}{|c|c|c|c|}
\hline Species & $\begin{array}{c}\text { Individuals } \\
\left(\delta^{\lambda}\right)\end{array}$ & Collection Site & Voucher Number \\
\hline Ctenus & 5 & Londrina $\left(23^{\circ} 19^{\prime} 37.5^{\prime \prime} \mathrm{S}, 51^{\circ} 12^{\prime} 13.4^{\prime \prime} \mathrm{W}\right), \mathrm{PR}$ & $\begin{array}{c}166439,167462,167463 \\
167466,167490\end{array}$ \\
\hline \multirow{4}{*}{$\begin{array}{l}\text { Ctenus } \\
\text { ornatus }\end{array}$} & 11 & Londrina $\left(23^{\circ} 19^{\prime} 37.5^{\prime \prime} \mathrm{S}, 51^{\circ} 12^{\prime} 13.4^{\prime \prime} \mathrm{W}\right), \mathrm{PR}$ & $\begin{array}{c}166426-166430,166440- \\
166442,166449,166458- \\
166459\end{array}$ \\
\hline & 9 & 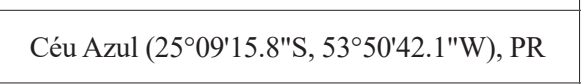 & $\begin{array}{l}166399-166401,167467- \\
167470,167476-167477\end{array}$ \\
\hline & 2 & 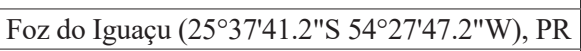 & 166416,167465 \\
\hline & 4 & Ubatuba (232 $\left.24^{\prime} 14.3^{\prime \prime S} 45^{\circ} 03^{\prime} 54.0^{\prime \prime} \mathrm{W}\right), \mathrm{SP}$ & $\begin{array}{c}166453-166454,167402 \\
167406\end{array}$ \\
\hline Enop & 3 & 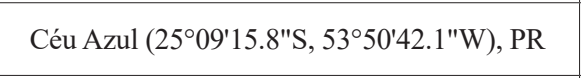 & $166397,166398,166407$ \\
\hline \multirow{3}{*}{$\begin{array}{l}\text { Phoneutria } \\
\text { nigriventer }\end{array}$} & 5 & Londrina $\left(23^{\circ} 19^{\prime} 37.5^{\prime \prime S}, 51^{\circ} 12^{\prime} 13.4^{\prime \prime} \mathrm{W}\right)$, PR & $\begin{array}{c}166441,167407,167489, \\
167494,167495\end{array}$ \\
\hline & 1 & Céu Azul (250' $\left.15.8^{\prime \prime S}, 53^{\circ} 50^{\prime} 42.1^{\prime \prime W}\right)$, PR & 166412 \\
\hline & 1 & 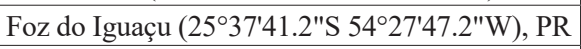 & 167405 \\
\hline \multirow{2}{*}{$\begin{array}{l}\text { Viracucha } \\
\text { andicola }\end{array}$} & 6 & Londrina $\left(23^{\circ} 19^{\prime} 37.5^{\prime \prime S}, 51^{\circ} 12^{\prime} 13.4^{\prime \prime} \mathrm{W}\right), \mathrm{PR}$ & $\begin{array}{c}166434,166445,166447, \\
167398-167400\end{array}$ \\
\hline & 2 & Céu Azul (2509'15.8"S, 5350'42.1"W), PR & 166411,166413 \\
\hline
\end{tabular}

chromosomes was classified according to Levan et al. (1964), using the MicroMeasure version 3.3 software (Reeves and Tear 2000). To determine the heterochromatin location and its composition, the slides were submitted to C-banding following Sumner (1972) and subsequently stained with base-specific fluorochromes, chromomycin $\mathrm{A}_{3}$ $\left(\mathrm{CMA}_{3}\right)$ and 4', 6-diamidino2-phenilindole (DAPI), according to the procedure described by Schweizer (1980).

\section{$18 \mathrm{~S}$ rDNA probe generation}

Genomic DNA of C. ornatus was extracted using a standard phenol/chloroform procedure (Sambrook and Russell 2006). A polymerase chain reaction (PCR) was performed with the primers of $18 \mathrm{~S}$ rDNA, forward: CGAGCGCTTTTATTAGACCA and reverse: GGTTCACCTACGGAAACCTT, as described by Forman et al. (2013). Another pair of primers was designed in the Primer3Plus software (Untergasser et al. 2007) to allow the complete amplification of the $18 \mathrm{~S}$ rDNA fragment, forward: TCTGTCTCGTGCGGCTAAAC and reverse: GATCCATTGGAGGGCAAGTC. The PCR reaction contained diluted genomic DNA, Taq buffer, $0.8 \mathrm{mM}$ dNTP mix, 4 $\mathrm{mM} \mathrm{MgCl}, 5$ pmol of each primer, and $2.5 \mathrm{U}$ of Taq polymerase (Invitrogen) for a reaction of $25 \mu$ l. The amplification was performed with an initial denaturation of 2 min at $94^{\circ} \mathrm{C}$, followed by 40 cycles of $1 \mathrm{~min}$ at $94^{\circ} \mathrm{C}, 1 \mathrm{~min}$ at $60^{\circ} \mathrm{C}$, and $5 \mathrm{~min}$ at $72{ }^{\circ} \mathrm{C}$ until completion. The $18 \mathrm{~S}$ rDNA was purified by agarose gel using the Pure 
Link-Quick Gel Extraction Kit (Invitrogen). The DNA fragment generated by the pair of primers described by Forman et al. (2013) was cloned using the kit pGEM-T Easy Vector System (Promega) in a suitable strain of Escherichia coli (TOP 10) and the insert was sequenced by the ABI-Prism 3500 Genetic Analyzer (Applied Biosystems).

The sequence was analyzed using the free software BioEdit, version 7.2.5 (Hall 2013). The rDNA sequence of $1280 \mathrm{pb}$, obtained from C. ornatus, was submitted to BLASTN (Altschul et al., 1990) in the National Center for Biotechnology Information (NCBI) database, through web site (http://www.ncbi.nlm.nih.gov/blast), to verify the homology with sequences of $18 \mathrm{~S}$ rDNA from spiders and demonstrated $99 \%$ of homology with Phoneutria fera Perty, 1833 (accession KY016373.1) in the GenBank. The sequence was deposited on NCBI, accession KT698160.1.

\section{Fluorescence in situ hybridization}

The $18 \mathrm{~S}$ rDNA sites were identified using the FISH technique according to Pinkel et al. (1986) and Gouveia et al. (2013), with the following modifications. After dehydration, the slides were treated with formamide $15 \% / \mathrm{SSC}$ for $10 \mathrm{~min}$ and subsequently in pepsin $(0.005 \mathrm{mg} / \mathrm{mL})$ for $20 \mathrm{~min}$. Probes were labeled with the Dig-Nick Translation kit (Invitrogen) and detected by the monoclonal anti-digoxigenin antibody conjugated to rhodamine (Roche Applied Science, Indianapolis, IN). Preparations were counterstained with DAPI. In the Ubatuba C. ornatus population, the slides were stained after a FISH procedure with $\mathrm{CMA}_{3}$ and DAPI to visualize the association between $18 \mathrm{~S}$ rDNA sites and GC-rich blocks. Finally, the slides were analyzed in an epifluorescence microscope (Leica DM 2000), equipped with a digital camera Moticam Pro 282B. The images were captured using the Motic Images Advanced software, version 3.2.

\section{Results}

Ctenus ornatus, Ctenus medius Keyserling, 1891, Phoneutria nigriventer, and Enoploctenus cyclothorax (Bertkau, 1880) exhibited $2 \mathrm{n}{ }^{\hat{\gamma}}=28$, as observed in mitotic metaphases (Fig. 1A, E, I, M), whereas Viracucha andicola presented 2n ${ }^{\lambda}=29$ (Fig. 1Q). All chromosomes were identified in metaphases II as acrocentric (Fig. 1D, H, L), except for E. cyclothorax and $V$. andicola, in which it was difficult to determine accurately the morphology of all chromosomes (Fig. 1P, T).

At male diakinesis 13 bivalents in all species were found and two univalent $\mathrm{X}$ in parallel association in the species with 28 chromosomes (Fig. 1C, G, K, O) and three univalent $\mathrm{X}$ in the species with 29 chromosomes (Fig. 1S). Three sex chromosomes in $V$. andicola showed parallel association (Fig. 1S-box). In some plates at pachytene and diplotene $\mathrm{X}$ are not associated in species with the two $\mathrm{X}$ chromosomes (Fig. 1C, G, K, O-boxes). Species with $2 \mathrm{n} \widehat{\widehat{O}}=28$ showed metaphases II with 13 and 15 chromosomes (Fig. 1D, H, L, P), and species with $2 \mathrm{n}{ }^{\lambda}=29$ showed cells with 13 and 16 


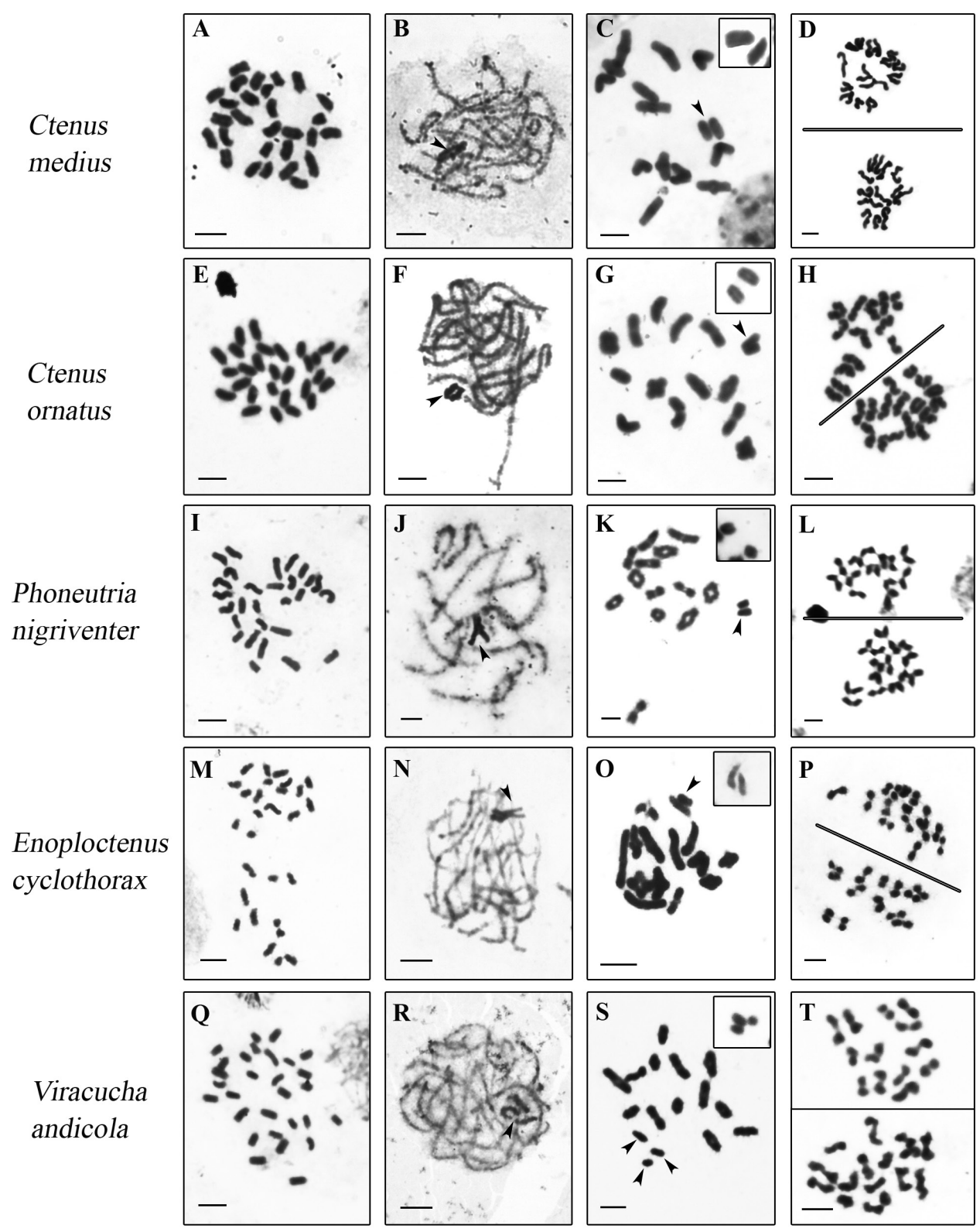

Figure I. Male mitotic and meiotic cells of Ctenidae species stained with Giemsa. Boxes - X chromosomes without association $(\mathbf{C}, \mathbf{G}, \mathbf{K}, \mathbf{O})$, and with association $(\mathbf{S})$. C. medius $(\mathbf{A}-\mathbf{D})$, C. ornatus $(\mathbf{E}-\mathbf{H})$, P. nigriventer (I-L), E. cyclothorax $(\mathbf{M}-\mathbf{P}), V$. andicola $(\mathbf{Q}-\mathbf{T})$. The arrowheads show sex chromosomes. Mitotic metaphases with $2 \mathrm{n}=28(\mathbf{A}, \mathbf{E}, \mathbf{I}, \mathbf{M})$ and $2 \mathrm{n}=29(\mathbf{Q})$. Pachytene cells $(\mathbf{B}, \mathbf{F}, \mathbf{J}, \mathbf{N}, \mathbf{R})$ with positively heteropycnotic sex chromosomes. Diakinesis cells $(\mathbf{C}, \mathbf{G}, \mathbf{K}, \mathbf{O}, \mathbf{S})$, note parallel association of two $\mathrm{X}$ chromosomes $(\mathbf{C}, \mathbf{G}, \mathbf{K}, \mathbf{O})$ or three $\mathrm{X}$ chromosomes without association $(\mathbf{S})$. Metaphase II cells with $\mathrm{n}=13$ and $\mathrm{n}=13+\mathrm{X}_{1} \mathrm{X}_{2}(\mathbf{D}, \mathbf{H}, \mathbf{L}, \mathbf{P})$ and $\mathrm{n}=13$ and $\mathrm{n}=13+\mathrm{X}_{1} \mathrm{X}_{2} \mathrm{X}_{3}(\mathbf{T})$. Bar $=10 \mu \mathrm{m}$. 


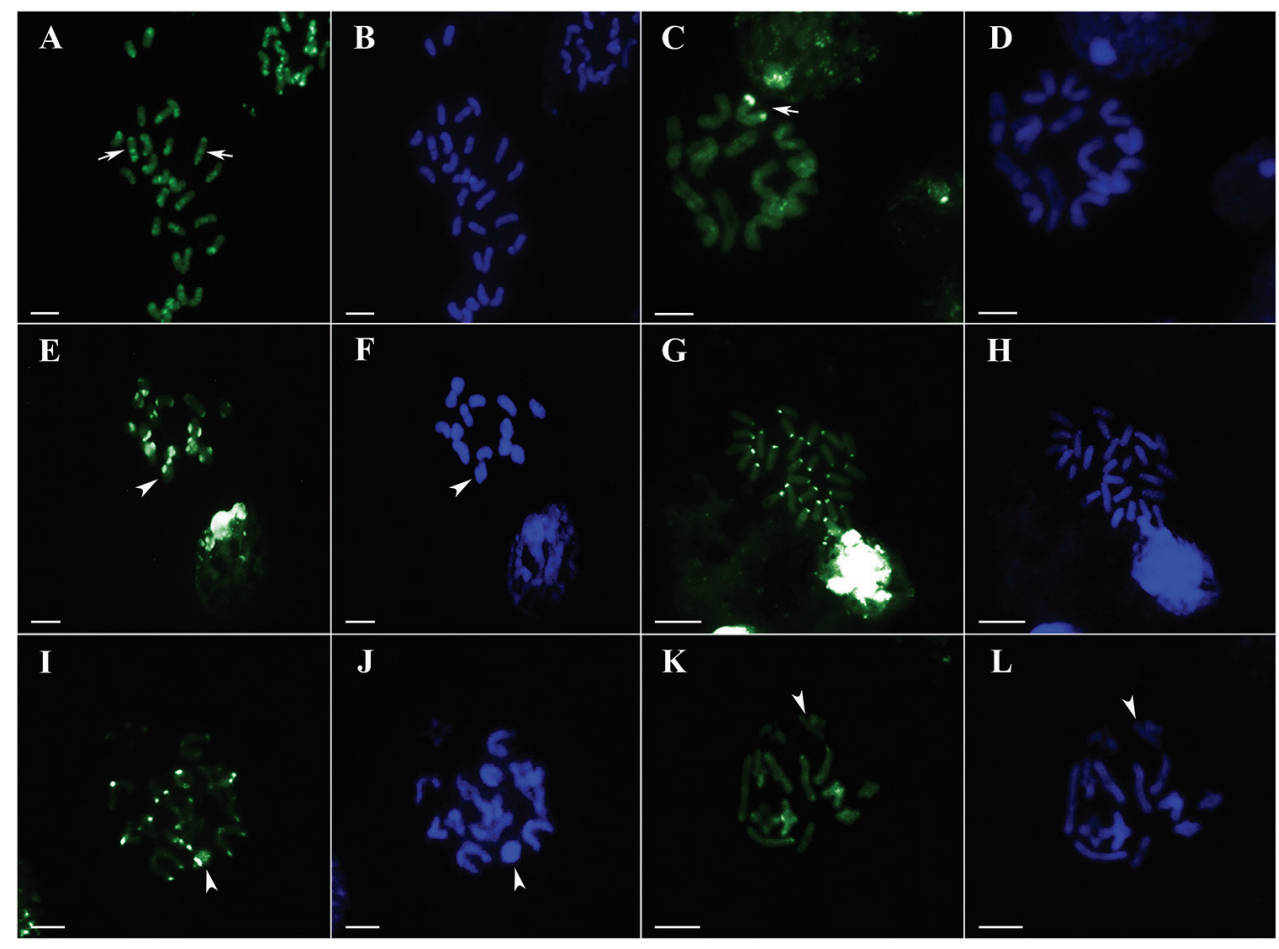

Figure 2. Ctenidae male mitotic and meiotic cells, C-banding and staining with base-specific fluorochromes $\mathrm{CMA}_{3}(\mathbf{A}, \mathbf{C}, \mathbf{E}, \mathbf{G}, \mathbf{I}, \mathbf{K})$ and DAPI (B, D, F, H, J, L). Arrowhead - X chromosomes. A, B mitotic metaphase of Ctenus ornatus, 28 chromosomes, arrow - interstitial $\mathrm{CMA}_{3}{ }^{+}$region $\mathbf{C}, \mathbf{D}$ diakinesis of $C$. ornatus, Ubatuba population, arrow - bivalent with large $\mathrm{CMA}_{3}{ }^{+}$block $\mathbf{E}, \mathbf{F}$ diakinesis of $C$. medius $\mathbf{G}, \mathbf{H}$ mitotic metaphase of Phoneutria nigriventer, $2 \mathrm{n}=28 \mathbf{I}, \mathbf{J}$ diakinesis of Viracucha andicola $\mathbf{K}, \mathbf{L}$ diakinesis of Enoploctenus cyclothorax. Bar $=10 \mu \mathrm{m}$.

chromosomes (Fig. 1T), that confirm sex chromosome systems of the types $\mathrm{X}_{1} \mathrm{X}_{2} 0$ and $\mathrm{X}_{1} \mathrm{X}_{2} \mathrm{X}_{3} 0$, respectively. In species with 28 chromosomes, two positively heteropycnotic bodies were observed in pachytene stage (Fig. 1B, F, J, N) and $V$. andicola exhibited three positive heteropycnotic bodies (Fig. 1R), identified as the sex chromosomes.

Ctenus ornatus presented interstitial and terminal $\mathrm{CMA}_{3}{ }^{+}$bands (Fig. 2A). Nevertheless, the population of Ubatuba (São Paulo state) presented an additional large terminal $\mathrm{CMA}_{3}{ }^{+}$block in a bivalent (Fig. 2C). In C. medius (Fig. 2E), P. nigriventer (Fig. 2G), V. andicola (Fig. 2I), and E. cyclothorax (Fig. 2K), all populations showed only $\mathrm{CMA}_{3}^{+}$ terminal blocks. Karyotypes contained no DAPI blocks (Fig. 2B, D, F, H, J, L).

The FISH revealed one bivalent with $18 \mathrm{~S}$ rDNA site in C. ornatus (Fig. 3A), C. medius (Fig. 3B), V. andicola (Fig. 3D), and E. cyclothorax (Fig. 3E). C. ornatus presented size polymorphism of the $18 \mathrm{~S} \mathrm{rDNA}$ site (Fig. 3A-box). P. nigriventer showed three bivalents exhibiting $18 \mathrm{~S}$ rDNA site; however, one of these bivalents presented site only in one chromosome (Fig. 3C). 

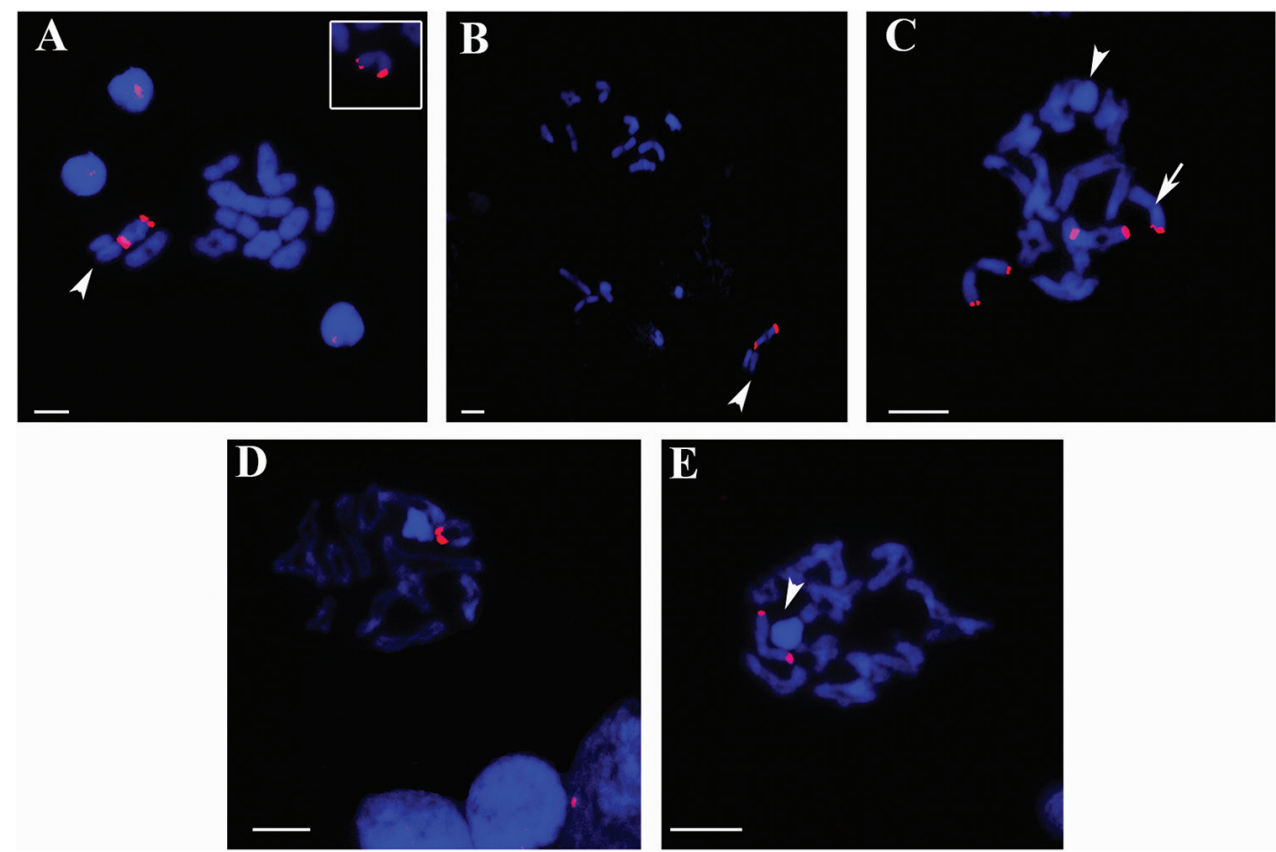

Figure 3. Ctenidae male meiotic cells, FISH with rDNA $18 \mathrm{~S}$ probe. Arrowhead - sex chromosomes. A diakinesis of Ctenus ornatus: in the box the bivalent with size heteromorphism of $18 \mathrm{~S}$ rDNA sites B diakinesis of Ctenus medius C diakinesis of Phoneutria nigriventer: arrow - bivalent with $18 \mathrm{~S} \mathrm{rDNA}$ sites in only one of the chromosomes D diplotene of Viracucha andicola $\mathbf{E}$ diplotene of Enoploctenus cyclothorax. $\operatorname{Bar}=10 \mu \mathrm{m}$.
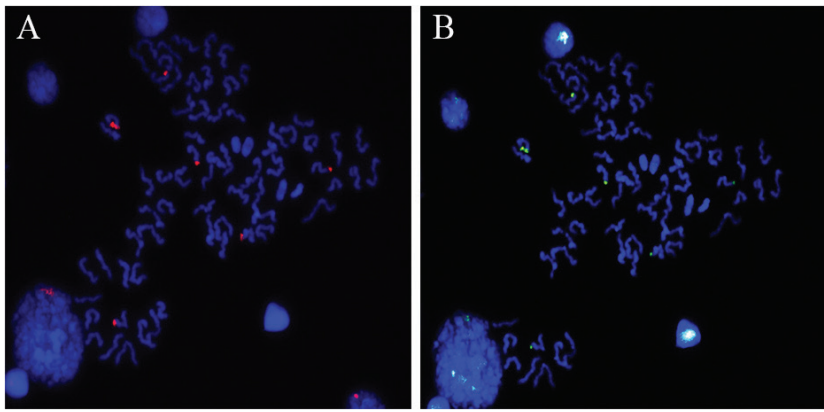

Figure 4. Chromosomes of Ctenus ornatus, Ubatuba/São Paulo state. A Metaphase II, FISH with rDNA $18 \mathrm{~S}$ probe $\mathbf{B}$ sequential staining with $\mathrm{DAPI} / \mathrm{CMA}_{3}$ in the same metaphase II, showing association between sites of GC-rich heterochromatin and rDNA $18 \mathrm{~S}$ regions. Note the presence of more than one metaphase II. Bar $=10 \mu \mathrm{m}$.

Metaphase II of $C$. ornatus from the Ubatuba population submitted to FISH and subsequently to CMA3/DAPI also revealed that $\mathrm{CMA}^{+}$sites with higher accumulation of GC-rich heterochromatin are co-localized to the sites carrying $18 \mathrm{~S}$ rDNA (Fig. 4). 


\section{Discussion}

The conventional analysis showed diploid number, chromosomal morphology, sex chromosome system and meiotic behavior of five Ctenidae species. The present study presents the first data for Acantheinae, increasing to four the number of ctenid subfamilies with cytogenetic data (Table 1), and the first cytogenetic study in C. medius and $E$. cyclothorax. In Ctenidae, the diploid number variation occurs basically due to the differences in SCS: species with $2 \mathrm{n} \hat{O}^{-}=28$ exhibit a SCS of the type $\mathrm{X}_{1} \mathrm{X}_{2} 0$, whereas species with $2 \mathrm{n} \hat{0}=29$ have the type $\mathrm{X}_{1} \mathrm{X}_{2} \mathrm{X}_{3}$. Only $A$. borellii (Viridasiinae) presents $2 \mathrm{n} \hat{0}=$ 22, with SCS of the type $\mathrm{X}_{1} \mathrm{X}_{2} 0$ (Chen 1999, Araujo et al. 2014, Kumar et al. 2016).

The parallel association between sex chromosomes during male meiosis is a common pattern observed in Entelegynae (Král et al. 2011; Araujo et al. 2012), and also found in Ctenidae (Chen 1999; Araujo et al. 2014; Kumar et al. 2016). Forman et al. (2013) observed absence of sex chromosome pairing in some plates of Wadicosa fidelis. They proposed that it might be due to chromosome preparation. A similar situation may have occurred in species analyzed in this study.

We observed two distinct distribution patterns of the GC-rich heterochromatin: (i) bands distributed in terminal regions of most chromosomes, as presented in C. medius, $P$. nigriventer, E. cyclothorax and $V$. andicola; and (ii) bands present in interstitial regions of most chromosomes, in addition to the terminal regions, as observed for $C$. ornatus. The first pattern could arise by dispersion of heterochromatin due to contact of chromosomes during their polarization of Rabl in mitosis or during bouquet orientation at the early prophase I as described by Schweizer and Loidl (1987). The second pattern could arise by occurrence of chromosomal rearrangements (Schweizer and Loidl 1987) or by spreading of the heterochromatin by transposable elements, as proposed for grasshopper (Rocha et al. 2015). Furthermore, despite the few species studied, GC-rich blocks seem to be common in entelegyne spiders (Araujo et al. 2005; Ramalho et al. 2008, Chemisquy et al. 2008). They were also found in Ctenidae species in the present study. The heterochromatin distribution also allowed to distinguish $C$. ornatus from Ubatuba population of other $C$. ornatus populations here analyzed.

The present study revealed a massive accumulation of GC-rich heterochromatin associated with $18 \mathrm{~S}$ rDNA site in C. ornatus from Ubatuba. Association of GC-rich heterochromatin with NORs is common in many animal groups, for example in fishes (Ferro et al. 2001) and amphibians (Schmid 1980). In spiders, this association has been reported in Nephilingys cruentata (Araneidae) (Araujo et al. 2005).

Another characteristic observed in C. ornatus was the size heteromorphism of $18 \mathrm{~S}$ rDNA sites. This can be explained by unequal crossing, which causes a greater accumulation of rDNA cistrons in one of the homologous chromosomes, as described by Ferro et al. (2001) and Teribele et al. (2008) in fish species. A similar situation may have occurred in P. nigriventer, very small $18 \mathrm{~S}$ rDNA sites could exhibit low fluorescence, making detection difficult. 
In Ctenidae, NOR in one bivalent seems to be the most commonly observed pattern. Only $P$. nigriventer presented more rDNA sites. This finding differs from Araujo et al. (2014), who observed only one chromosome pair carrying NOR in the same species using the silver nitrate impregnation that identifies only transcriptionally active sites. Specimens of $V$. andicola showed a single NOR as revealed by the FISH analysis. By contrast, the data exhibited by Araujo et al. (2014) showed NORs in two chromosome pairs, which could indicate an interpopulation variation, however the authors analyzed only one specimen, which hinders a more accurate study.

The present study brings new cytogenetic information and first FISH data for Ctenidae providing valuable contribution to the knowledge on karyotypes in this family.

\section{Acknowledgments}

The authors thank Dra. Renata da Rosa (UEL), reviewers and the sub-editor of Comparative Cytogenetics for their considerations and time in reviewing this article, and to Dra. Juceli Gonzalez Gouveia (UEMS) for his assistance related to molecular cytogenetic techniques. Authors also thank to Rafael Campos de Barros, Mailson Gabriel da Fonseca, and Robson Rockembacher (UEL) for their assistance with sample collection. This work was supported by the Capes and CNPq (ADB grant PQ 301776/2014-0; ALD grant 312529/2014-7).

\section{References}

Altschul SF, Gish W, Miller W, Myers EW, Lipman DJ (1990) Basic local alignment search tool. Journal of Molecular Biology 215(3): 403-410. https://doi.org/10.1016/S00222836(05)80360-2

Araujo D, Cella DM, Brescovit AD (2005) Cytogenetic analysis of the neotropical spider Nephilengys cruentata (Araneomorphae, Tetragnathidae): standard staining NORs, Cbands, and base-specific fluorochromes. Brazilian Journal of Biology 65(2): 193-202. https://doi.org/10.1590/S1519-69842005000200002

Araujo D, Rheims CA, Brescovit AD, Cella DM (2008) Extreme degree of chromosome number variability in species of the spider genus Scytodes (Araneae, Haplogynae, Scytodidae). Journal of Zoological Systematics and Evolutionary Research 46(2): 89-95. https://doi. org/10.1111/j.1439-0469.2007.00457.x

Araujo D, Schneider MC, Paula-Neto E, Cella DM (2012) Sex chromosomes and meiosis in spiders: a review. In: Swan A (Ed.) Meiosis - Molecular Mechanisms and Cytogenetic Diversity. InTech, Croatia, Rijeka, 87-108. https://doi.org/10.5772/31612

Araujo D, Oliveira EG, Giroti AM, Mattos VF, Paula-Neto E, Brescovit AD, Schneider MC, Cella DM (2014) Comparative cytogenetics of seven Ctenidae species (Aranae). Zoological Science 31(2): 83-88. https://doi.org/10.2108/zsj.31.83 
Araujo D, Schneider MC, Paula-Neto E, Cella DM (2017) The spider cytogenetic database. www.arthropodacytogenetics.bio.br/spiderdatabase [Accessed in: 28/04/2017]

Bole-Gowda BN (1952) Studies on the chromosomes and the sexdetermining mechanism in four hunting spiders (Sparassidae). Proceedings of the Zoological Society of Bengal 5: 51-70.

Chemisquy MA, Rodríguez-Gil SG, Scioscia CL, Mola LM (2008) Cytogenetic studies of three Lycosidae species from Argentina (Arachnida, Araneae). Genetics and Molecular Biology 31: 857-867. https://doi.org/10.1590/S1415-47572008005000022

Chen S (1999) Cytological studies on six species of spiders from Taiwan (Araneae: Theridiidae, Psechridae, Uloboridae, Oxyopidae, and Ctenidae). Zoological Studies 38(4): 423-434.

Ferro DAM, Néo DM, Moreira-Filho O, Bertollo LAC (2001) Nucleolar organizing regions, $18 \mathrm{~S}$ and $5 \mathrm{~S}$ rDNA in Astyanax scabripinnis (Pisces, Characidae): populations distribution and functional diversity. Genetica 110(1): 55-62. https://doi.org/10.1023/A:1017963217795

Forman M, Nguyen P, Hula V, Král J (2013) Sex chromosome pairing and extensive NOR Polymorphism in Wadicosa fidelis (Araneae: Lycosidae). Cytogenetic and Genome Research 141(1): 43-49. https://doi.org/10.1159/000351041

Gouveia JG, Moraes VPO, Sampaio TR, Rosa R, Dias AL (2013) Considerations on karyotype evolution in the genera Imparfinis Eigenmann and Norris 1900 and Pimelodella Eigenmann and Eigenmann 1888 (Siluriformes: Heptapteridae). Review in Fish Biology and Fisheries 23(2): 215-227. https://doi.org/10.1007/s11160-012-9286-2

Hall T (2013) BioEdit, version 7.2.5. Ibis Biosciences, Carlsbad, CA, USA.

Král J, Musilová J, Štáhlavský F, Řezáč M, Akan Z (2006) Evolution of the karyotype and sex chromosome systems in basal clades of araneomorph spiders (Araneae: Araneomorphae). Chromosome Research 14(8): 859-880. https://doi.org/10.1007/s10577-006-1095-9

Král J (2007) Evolution of multiple sex chromosomes in the spider genus Malthonica (Araneae: Agelenidae) indicates unique structure of the spider sex chromosome systems. Chromosome Research 15: 863-879. https://doi.org/10.1159/000323497

Král J, Korínková T, Forman M, Krkavcová L (2011) Insights into the meiotic behavior and evolution of multiple sex chromosome systems in spiders. Cytogenetic and Genome Research 133(1): 43-66. https://doi.org/10.1159/000323497

Král J, Korínková T, Krkavcová L, Musilová J, Forman M, et al (2013) Evolution of karyotype, sex chromosomes, and meiosis in mygalomorph spiders (Araneae: Mygalomorphae). Biological Journal of the Linnean Society 109(2): 377-408. https://doi.org/10.1111/bij.12056

Kumar AS, Venu G, Jayaprakash G, Venkatachalaiah G (2016) Studies on chromosomal characteristics of Ctenus indicus (Gravely 1931) (Araneae: Ctenidae). The Nucleus. https://doi. org/10.1007/s13237-016-0191-2

Levan A, Fredga K, Sandberg AA (1964) Nomenclature for centromeric position on chromosomes. Hereditas 52(2): 201-220. https://doi.org/10.1111/j.1601-5223.1964.tb01953.x

Ministérios da Saúde (2017) SISNAM. http://www.portalsinan.saude.gov.br [Acessed in: 05/02/2017]

Parida BB, Sharma NN (1986) Karyotype and spermatogenesis in an Indian hunting spider, Sparassus sp. (Sparassidae: Arachnida) with multiple sex chromosomes. Chromosome Information Service 40: 28-30. 
Pätau K (1948) X-segregation and heterochromasy in the spider Aranea reaumuri. Heredity 2: 77-100. https://doi.org/10.1038/hdy.1948.5

Pinkel D, Straume T, Gray JW (1986) Cytogenetic analysis using quantitative, high-sensitivity, fluorescence hybridization. Proceedings of the National Academy of Sciences of United States of America 83(9): 2934-2938. https://doi.org/10.1073/pnas.83.9.2934

Polotow D, Brescovit AD (2014) Phylogenetic analysis of the tropical wolf spider subfamily Cteninae (Arachnida, Araneae, Ctenidae). Zoological Journal of the Linnean Society 170(2): 333-361. https://doi.org/10.1111/zoj.12101

Postiglioni A, Brum-Zorrilla N (1981) Karyological studies on Uruguayan spiders II. Sex chromosomes in spiders of the genus Lycosa (Araneae-Lycosidae). Genetica 56(1): 47-53. https://doi.org/10.1007/BF00126929

Ramalho MO, Araujo D, Schneider MC, Brescovit AD, Cella DM (2008) Mesabolivar brasiliensis (Moenkhaus 1898) and Mesabolivar cyaneotaeniatus (Keyserling 1891)(Araneomorphae, Pholcidae): close relationship reinforced by cytogenetic analyses. Journal of Arachnology, 36(2): 453-456. https://doi.org/10.1636/CSh07-132.1

Reeves A, Tear J (2000) MicroMeasure for Windows, version 3.3. Free program distributed by the authors over the Internet from http://www.colostate.edu/Depts/Biology/MicroMeasure

Rocha MF, Pine MB, dos Santos Oliveira EFA, Loreto V, Gallo RB, da Silva CRM, de Domenico FC, da Rosa R (2015) Spreading of heterochromatin and karyotype differentiation in two Tropidacris Scudder, 1869 species (Orthoptera, Romaleidae). Comparative Cytogenetics 9(3): 435-450. https://doi.org/10.3897/CompCytogen.v9i3.5160

Sambrook J, Russell DW (2006) Purification of nucleic acids by extraction with phenol: chloroform. Cold Spring Harbor Protocols. https://doi.org/10.1101/pdb.prot4455

Schmid M (1980) Chromosome banding in Amphibia. IV. Differentiation of GC- and ATrich chromosome region in Anura. Chromosoma 77(1): 83-103. https://doi.org/10.1007/ BF00292043

Schweizer D (1980) Simultaneous fluorescent staining of R bands and specific heterochromatic regions (DA-DAPI bands) in human chromosomes. Cytogenetic and Genome Research 27: 190-193. https://doi.org/10.1159/000131482

Schweizer D, Loidl J (1987) A model for heterochromatin dispersion and the evolution of C-bands patterns. In: Stahl A, Luciani JM, Vagner-Capodano AM (Eds) Chromosomes Today. Allen \& Unwin, London, 61-74. https://doi.org/10.1007/978-94-010-9166-4_7

Silva-Dávila D (2003) Higher-level relationships of the spider family Ctenidae (Araneae: Ctenoidea). Bulletin of the American Museum of Natural History 274: 1-86. https://doi. org/10.1206/0003-0090(2003)274<0001:HLROTS>2.0.CO;2

Sumner AT (1972) A simple technique for demonstrating centromeric heterochromatin. Experimental Cell Research 75(1): 304-306. https://doi.org/10.1016/0014-4827(72)90558-7

Suzuki G, Kubota S (2011) 5S ribosomal DNA cluster of a lynx spider Oxyopessertatus includes a histone H2B-like gene in the spacer region (NTS). Chromosome Science 14: 3-8. https://doi.org/10.11352/scr.14.3

Teribele R, Gravena W, Carvalho K, Giuliano-Caetano L, Dias AL (2008) Karyotypic analysis in two species of fishes of the family Curimatidae: AgNO3, CMA3 and FISH with $18 \mathrm{~S}$ probe. Caryologia 61(3): 211-215. https://doi.org/10.1080/00087114.2008.10589632 
Untergasser A, Nijveen H, Rao X, Bisseling T, Geurts R, Leunissen JAM (2007) Primer3Plus, an enhanced web interface to Primer3. Nucleic Acids Research 35 (suppl_2): W71-W74. https://doi.org/10.1093/nar/gkm306

Vítkóva M, Král J, Traut W, Zrzavý J, Merec F (2005) The evolutionary origin of insect telomeric repeats, (TTAGG) ${ }_{n}$. Chromosome Research 13: 145-156. https://doi.org/10.1007/ s10577-005-7721-0

Zhao Y, Ayoub NA, Hayashi CY (2010) Chromosome mapping of dragline silk genes on the genomes of widow spider (Araneae, Theridiidae). PLoS ONE 5(9): e12804. https://doi. org/10.1371/journal.pone.0012804

World Spider Catalog (2017) The World Spider Catalog, version 18.0. American Museum of Natural History. http://www.wsc.nmbe.ch [Accessed on: 24/06/2017] 